DOI https:/ / doi.org/10.32837/app.v0i64.187

УДК 342.7:172.3

Бальжик I. A.* (НУ «ОЮА»)

\title{
ГІДНІСТЬ І СВОБОДА ЯК БАЗОВІ ХРИСТИЯНСЬКІ ЦННОСТІ КОНЦЕПТУ ПРАВ ЛЮДИНИ
}

\section{DIGNITY AND FREEDOM AS BASIC CHRISTIAN VALUES OF THE HUMAN RIGHTS CONCEPT}

*Irena Balzhyk - PhD in Law, Associate Professor at the Department of General Theoretical Jurisprudence, National University "Odesa Law Academy", (23 Fontanska Doroha str., Odesa, Ukraine).

\section{Abstract}

Interpretations of human rights issues from the state-legal point of view and state-secular ideology and practice, on the one hand, and from the point of view of the modern Orthodox doctrine of man and his or her rights, on the other, do not always coincide. However, both approaches are based on the fact that human rights must be inviolable, inalienable, equal for all people, who must be equal before the law regardless of their attitude to religion.

The Orthodox Church argues that the principle of freedom must be in harmony with morality and faith. This harmonization should be reflected in the law, because, according to the church, the moral for all is one, because it is the meaning of the Ten Commandments of God.

The dignity of the individual is the basis of all human existence and interaction with other individuals. Fixing the dignity of the individual in legal norms gives this quality of personal existence legal properties, which creates the opportunity to consider this category as one of the fundamental and subjective human rights.

From the standpoint of Orthodoxy, the basis of human dignity is the belief that each person is truly a sacred person, the creation of God. At the heart of the dignity of a person who lives in Christ is the conviction that the Holy Spirit is present in his life. In accordance with its dignity, a person is called to good works.

The main feature of the church's understanding of human rights is to assess the role and place of moral values in the life of modern society. Specificity is 
the presence of a comparative-evaluative connection of Christian anthropology and ethics with human rights theory.

Keywords: Christianity, Orthodoxy, law, human rights, Christian legal tradition, dignity, freedom.

Базовим поняттям, на яке спирається теорія прав людини, є поняття людської гідності. Сама концепція прав людини можлива тільки при визнанні гідності та свободи людини. I християнська підстава для цього існує: «людина створена за образом і подобою Бога» і наділена свободою Самим Богом. Відповідно до біблійного одкровення, природа людини не тільки створена Богом, але й наділена Ним властивостями за Його образом і подобою (Бут. 1, 26). Тільки на цій підставі можна стверджувати, що людська природа володіє невід'ємною гідністю. Святитель Григорій Богослов, співвідносячи людську гідність з актом Божественного творіння, писав: «Так щедро всіх людей наділив Бог, звичайно, для того, щоб однаковим роздаванням дарів Своїх показати й однакову гідність нашої природи, й багатство благості Своєї» (Слово 14, «Про любов до бідних»).

Втілення Бога Слова засвідчило, що і після гріхопадіння гідність не була втрачена людською природою, бо в ній залишився незнищенним образ Божий, а значить, і можливість відновлення людського життя в повноті його початкової досконалості. Вивчення уявлень Святих отців про гідність людини набуває чималу значимість, оскільки детальний аналіз церковної спадщини дозволяє аргументовано вирішувати питання про ступінь узагальнення і редукування святоотецьких положень, відображених в документі, який представляє сучасну концепцію УПЦ про права людини.

Процеси, пов'язані зі зростаючою роллю релігії в сучасному суспільстві, породжують інтерес до вчень про сутність і призначення людини, заснованих на священних текстах і віроповчальній традиції. У працях Фоми Аквінського вироблено розуміння «гідності» (а також пов' язаних з ним понять особистості, свободи вибору і т. д.), яке багато в чому схоже з його розумінням Нового часу (наприклад, у Канта) і разом з тим відмінне від нього низкою елементів. Цей факт представляє інтерес як для зіставлення уявлень про гідність в різні епохи, так і для можливостей використання таких елементів з метою переосмислення і розвитку поняття гідності. Звернення до робіт Фоми Аквінського також важливе для розуміння того, звідки і яким чином походить таке теологічно фундоване поняття. 
Саме слово «гідність» Фома Аквінський використовує в різних сенсах і різних контекстах, не тільки для позначення сутнісного властивості особистості По-перше, слово «гідність» використовується для перекладу грецького слова «аксіома», також етимологічно пов' язаного з поняттям «аксіос», гідний. У цьому сенсі гідність - це основоположення, ясне саме по собі, що необхідним чином знаходиться в розумі і наділяє ясністю і необхідністю всі інші положення, засновані на ньому. По-друге, це слово відноситься до божественної суті і активно використовується в тринітарних спорах. Третє слововживання, у ставленні до людської особистості, можна розглядати як джерело сучасного вживання. Гідність - це те, що притаманне особистості в їі єдності і унікальності і $є$ іï основою (відзначимо, що в сучасному розумінні скоріше з особистості виникає ії гідність, ніж з гідності особистість). Гідність особистості позначає, що вона не може використовуватися як засіб, але сама є метою в собі (Бандуровский, 2017).

Права людини включають в себе комплекс світоглядних і філософських понять, що стосуються людини і суспільства, ключовими з яких є поняття гідність і свобода. У філософській літературі гідність людини - це філософське поняття, що виражає позитивне значення особистості, його соціальної діяльності. Позитивність виявляється, перш за все, в тому, що «людина - найвища цінність». У цій повній сенсу тезі, в цій ідеї, що містить життєву філософію, відображено те, що кожна людина має індивідуальну соціально-духовну значущість, абсолютну цінність. Поняття людської гідності пов' язане із самою сутністю людяності. У 1948 році була створена «Декларація прав людини» в Преамбулі якої записано: «Всі люди рівні в своїй гідності, Гідність притаманна всім членам людської сім'ї». Основна соціальна цінність, абсолютна гідність людини не в тому, що вона є основною продуктивною силою в створенні матеріальних і духовних благ, а в тому, що особистість існує в просторі і часі як самостійна одиниця, що має свої цілі, свої недоторканні права і свободи. Життя людини, iï гідність, ії цінність своїми соціологічними і гносеологічними коріннями тісно пов’ язані з гуманізмом. Гуманізм означає «боротьбу за всебічно прояв цінності людини, її свободи, здібностей, забезпечення щастя людини, його рівноправній, справедливого життя, створення всіх умов для прояву всіх принципів людяності» (Усманов, 2015).

Гідність є центральним поняттям прав людини і одним 3 основних понять моральності. Зміст поняття «гідність» багатогранний і багатоаспектний. Залежно від підходу воно може виступати і 
універсальною етичною максимою, і юридичною формою захисту гідності особистості в галузях права, і засобом соціальної комунікації. Традиція природного права визначає гідність як основоположну правову ідею і моральну категорію, так само значущу для етичної та юридичної нормативно-ціннісної системи. Можливість такої точки зору підтверджує розвиток теоретичного поняття «гідність» в історії філософської і політико-правової думки. Гідність, будучи однією з основних категорій прав людини, втілює в собі цінності як моралі, так і права і перебуває ніби на стику цих двох нормативно-ціннісних систем. Вона співвідноситься з індивідуальним проявом людського духу (моральна характеристика). Окреме відчуття моральної гідності як самоповаги може бути різним, але гідність, значимість людини перед законом однакова. Мораль вимагає поваги гідності людини незалежно від його походження, статусу і переконань. Право вимагає рівності перед законом, рівності вимог людей до гідності і іï захист. Обидві нормативні системи спрямовані на одну мету - забезпечення і захист гідності людини в рамках регуляції суспільних відносин (Кантипенко, 2015).

Гідність і честь - поняття моральної свідомості, етичні категорії, полісемантичного поняття. В етиці всебічно розроблені теоретичні основи і співвідношення цих категорій. Гідність ототожнюється з цінністю людини (людини взагалі або конкретної особистості) або з усвідомленням нею цієї цінності, або з поведінкою людини, що виражається в гідному способі життя. Найважливіший аспект змісту гідності - в свідомості відсутності примусу, тобто свідомості свободи. Умовою реалізації гідності людини є свобода. Свобода цінності людини в більшості випадків не усвідомлювана, прихована в несвідомому. Поки вона є, людина не втрачає свою людську гідність. Йдеться про цінності будь-якого людського істоти, незалежно від національних, культурно-цивілізаційних, історичних кордонів і особливостей, про цінність людського взагалі, про людську гідність (Власова, 2011).

Питання про свободу в теоретичному сенсі є філософським питанням, що має багато вимірів - соціальне, психологічне, моральне, і без перебільшення можна сказати: це дуже складне і важливе питання.

Розуміння свободи відрізняються значною різноманітністю. Розглянемо деякі з них: метафізичне, коли під свободою мається на увазі одна з найбільш фундаментальних властивостей людської природи - свобода волі, що виражається у внутрішньому само- 
визначенні особистості перед обличчям добра і зла. Свобода волі $є$ тією властивістю, втрата якої призводить до повної деградації особистості. Над цією свободою людини, за християнським вченням, не може панувати ніхто: ні інша людина, ні суспільство, ні закони, ні Сам Бог.

Однак, коли акт волі особистості повинен «матеріалізуватися», здійснитися зовні, в соціальному середовищі, він стикається з безліччю обмежень. Так виникає проблема зовнішньої свободи і прав людини, тобто проблема дозволених (законом, звичаями, суспільною мораллю) вчинків в навколишньому світі, в суспільстві.

I третя категорія - свобода духовна. Вона означає владу людини над своїм егоїзмом, своїми пристрастями, гріховними почуттями, бажаннями - над самим собою. Така свобода набувається тільки при правильному християнському житті, що робить християнина здатним до спілкування з Богом, чому Апостол Павло і пише: ... де Дух Господній, там свобода (2 Кор. 3, 17).

Три зазначені категорії свободи дозволяють 3 повною впевненістю говорити про те, яка свобода повинна бути вищою метою кожної людини i, перш за все, християнина, який знає Свангеліє і вірить йому. Це, безумовно, свобода духовна, яка з'являється в процесі православного аскетичного життя. Історично склалося так, що свобода формування і вираження світоглядних і інтуїтивно-релігійних установок свідомості людини стала називатися «свободою совісті».

Бердяєв Н.А. дає наступне визначення: «Свобода совісті - основа будь-якого права на свободу, тому вона не може бути скасована або обмежена людською волею, державною владою. Вона є виявлення Бога. Бог в свободі бачить гідність створеної Ним людини. Тільки у вільній істоті образ і подоба Божі виявляються».

Феномен совісті поза релігійного контексту нез'ясовний. Саме тому виникає необхідність викласти церковний погляд (зокрема православної церкви, далі - Церква) на гідність людини з метою позначення її прав, можливих і неприйнятних.

Церква пояснює совість як основу моральності, закладену Творцем. «Вічний моральний закон має в душі людини тверду основу, незалежну від культури, національності, життєвих обставин. Ця основа закладена Творцем в людську природу і проявляється в совісті».

Часто права людини розуміються як щось світське, що не має ніякого відношення до релігійності; за права людини часто боролися люди нерелігійні, але, як відзначали багато дослідників, саму 
ідею свободи і свідомість права на свободу вони почерпнули саме в християнстві.

Права людини стали важливим інститутом сучасного суспільного і державного ладу. Його привабливість заснована на простій і доступній ідеї, відповідно до якої в центр суспільного життя ставиться турбота про благо кожної окремої людини. Інститут прав людини є надзвичайно важливим для побудови громадянського суспільства і правової держави, однак православна церква визначає і деякі недоліки цього інституту.

На думку Церкви, чим більше розвивається інститут прав людини, тим менше законодавець враховує моральні виміри життя і свободу від гріха (2) (ч. II. 2). Відповідно до християнського вчення гріх спотворює природу людини.

Права людини, перш за все, потрібні людині для того, щоб, володіючи ними, вона могла найкращим способом виконувати своє високе призначення «подоби Божої». Одностороннім, на думку Церкви, $є$ розуміння прав людини як категорії, що пояснює всю повноту свободи людської особистості. Гідність, дана людині Богом, доповнюється і тими перевагами, яких вона набуває праведним життям. Щоб заслужити цю гідність, людина повинна мати совість, закладену в неї Богом. Права людини, пов' язані з моральною відповідальністю, i їх використання повинно бути направлено на реалізацію гідності людини. Ще грецькі Отці Церкви стверджували, що Бог створив людей вільними, а тому і відповідальними за їхні вчинки. Очевидно, що відповідальність людини безпосередньо пов'язана з іï гідністю. Тому людина повинна жити гідно, усвідомлюючи відповідальність за свій спосіб життя.

Розглядаючи поняття «свобода», Церква визначає, що «головний виклик полягає не в дефіциті свободи, а в тому, «як нею користуються народи і окремі особистості», оскільки «історичний досвід показує: свобода без обмежень поїдає сама себе». Тому в Декларації проводиться розрізнення двох свобод - «внутрішньої свободи від зла і свободи морального вибору», де «свобода від зла є самоцінною; свобода ж вибору набуває цінність, а особистість - гідність, коли людина вибирає добро»; з точки зору Декларації, «людина повинна користуватися своєю свободою на користь і вдосконалення, а не для руйнування свого життя і життя оточуючих людей» (Декларация о правах и достоинстве человека).

Православна церква стверджує, що принцип свободи повинен бути гармонізований 3 мораллю і вірою (ч. III. 2., 8, 25). Ця гармоні- 
зація повинна бути відображена в законодавстві, оскільки, на думку церкви, мораль для всіх одна, адже нею вважається зміст десяти заповідей Божих. Ці заповіді визнають всі основні релігії світу і світська етика солідаризується 3 ними. Церква наполягає на тому, що реалізація прав і свобод можлива тільки в цій системі цінностей. 3 точки зору церкви, єдність моралі побудовано на таку рису людини, як совість. Християнство вважає, що совість - це закладений в людині божественний закон, який підказує їй, що є небезпечним для неї, а що ні.

Говорячи про права людини, Декларація заявляє про їх «нерозривний зв' язок з обов' язками і відповідальністю людини» і виступає «за право на життя і проти права на смерть, за право на творення i проти права на руйнування», вважаючи, що «права людини мають підставою цінність особистості і повинні бути спрямовані на реалізацію їі гідності».

Інтерпретації проблематики прав людини з державно-юридичної точки зору і державно-світської ідеології і практики, з одного боку, і з позиції сучасної православної доктрини про людину та ії права, - $з$ іншого, не завжди збігаються. Однак ці обидва підходи засновані на тому, що права людини повинні бути непорушними, недоторканними, однаковими для всіх людей, які повинні бути рівні перед законом незалежно від їх ставлення до релігії.

Головний заклик Декларації полягає в необхідності «створити сильний моральний вимір в суспільстві, який б задавав правильний вектор людської свободи», тобто необхідності введення, а точніше, повернення морального виміру, моральної системи координат в сучасну громадську і правову систему, а таким чином, в необхідності християнського переосмислення цих найважливіших цінностей, що лежать в основі європейської цивілізації (Декларация о правах и достоинстве человека).

Суть поняття «людська гідність» бачиться в онтологічній основі прав людини, у взаємній повазі суспільства і особистості, держави і громадянина, людини і людини, тобто в толерантності. Мислителі минулого бачили гідність і честь людини в його правах і свободах. Без прав людини його цінність стає нереальним поняттям.

У свою чергу, права людини теж починаються з усвідомлення іiі гідності та цінності. Отже, в суспільному житті «кожна людина найвища цінність», і в процесі такого становлення особистість для держави і суспільства, держава і суспільство для особистості скла- 
дають цінність. Особистість в усвідомленні цінності себе та інших, повинна володіти також і правами людини. Таким чином, можна зробити висновок, що поняття гідності людини отримало свій розвиток 3 морального почуття і обов' язки людини по відношенню до себе. Ставши універсальним принципом прав людини, воно увібрало в себе і моральний аспект.

Тому, хоча основною умовою правової категорії «гідність» є його визнання і повага, це не тільки оціночне поняття, що характеризує індивіда як особистість, що володіє самоцінністю. Моральна «характеристика людини з точки зору його внутрішньої цінності, відповідності своєму призначенню» доповнюється імперативним приписом людині бути гідним. Людина зберігає почуття самоповаги і відчуття власної значущості, тобто почуття власної гідності, якщо іï дії і вчинки схвалюються іншими людьми. Тільки через визнання рівного і рівноцінного гідності інших можна трактувати гідність як загальнолюдське поняття. У цій своїй якості гідність людини є загальним правовим принципом, фундаментальним правом людини, з якого походять такі права, як право на життя і рівноправність у всіх його проявах. Воно визначає недоторканність усіх цих прав, а також неможливість посягання на гідність людини, як би воно не проявлялося. Право на гідність розкривається через комплекс відносин держави до людини, людини до самої себе і іншим людям. Тому гідність людини може розглядатися одночасно як етичне i, разом 3 тим, юридичне поняття. Воно тісно пов'язане як з встановленням i забезпеченням прав і свобод людини, так і з формуванням загальної культури суспільства, всієї системи загальнозначущих цінностей: від рівності і свободи до гідного життя людини за прийнятними соціально-економічним стандартам (Кантипенко, 2015).

Гідність особистості - це основа всього існування людини і взаємодії з іншими індивідами. Закріплення гідності особистості в правових нормах надає цій якості особистого існування правові властивості, що створює можливість розглядати дану категорію в якості одного з основних і суб'єктивних прав людини. Права людини невіддільні від людей, від їх суспільних відносин, способів буття індивіда. Вони органічно вплетені в суспільні відносини, є формою взаємодії людей, упорядкування їх зв' язків, координації їх вчинків і діяльності, запобігання протиріч, протиборства, конфліктів. За своєю суттю права людини нормативно формулюють ті умови і способи життєдіяльності людей, які об'єктивно необхідні для забезпечення нормального 
функціонування індивіда, суспільства, держави. Такі права, як право на життя, на гідність, недоторканість особи, свободу совісті, думок, переконань, автономію приватного життя, інформацію і т. п., є необхідними умовами влаштування життя людини в цивілізованому суспільстві і повинні бути беззастережно визнані і охороняють державою. Разом з тим, через помічену в останні роки в нашій країні деформацію моральності, виявилися деформованими і багато уявлень про права особистості, в тому числі і про їі гідність. Гідність людини стала вимірюватися не за особистими позитивними якостями, а й за вмінням влаштуватися в житті будь-якими шляхами. Зовнішні атрибути благополуччя і багатства людини, чужі людської сутності, стали мірилом його честі і гідності (Усманов, 2015).

Людська гідність - основа і серцевина концепції прав людини. Німецький філософ і соціолог Ю. Хабермас, кажучи про неординарний характер людської гідності стверджує, що гідність «слід вважати не просто класифікують виразом, свого роду муляжем, за яким ховається безліч різних феноменів, але моральним» витоком, «який за змістом живить всі базисні права» (Малер-Матязова).

3 позиції православ'я, в основі гідності людини лежить впевненість, що кожна людина є воістину сакральним особою, творінням Бога. В основі гідності людини, що живе у Христі, лежить переконаність в тому, що в його житті присутній Святий Дух. У відповідності зі своїм достоїнством людина покликана до добрих справ.

Головна особливість церковного розуміння прав людини - в оцінці ролі і місця моральних цінностей в житті сучасного суспільства. Специфіка полягає в наявності порівняльно-оцінної зв'язку християнської антропології та етики з теорією прав людини. Подальше дослідження проблеми гідності людини гостро необхідно в зв'язку 3 тенденцією до зміни уявлень про гідність кожного, рівність всіх і невід'ємних і загальних правах людини.

\section{Лimepamypa:}

Бандуровский, К. (2017). Понятие достоинства в философии Фомы Аквинского. Достоинство как историческое понятие и центральная категория нашего времени: материалы конференции (г. Москва, 2-4 июня 2017 г.). Москва, 10-11.

Власова, О. В. (2011). Достоинство человека как нравственно-правовая ценность: общетеоретическое исследование: дис. ... д.-ра юрид. наук: 12.00.01. Ханты-Мансийск. 
Говорун, С. (2006). В оправдание человеческого достоинства. Человек. История. Весть. Київ: Дух і Література, 34-41.

Грищук, О. В. (2007). Людська гідність у праві: фрілософський аспект: дис. ... д-ра юрид. наук: 12.00.12. Львів.

Декларация оправахидостоинствечеловека.URL:http:/ /www.mospat.ru/ archive/30728.htm.

Кантипенко, Е. А. (2015). Развитие понятия «Достоинство человека» как нравственно-правовой категории концепции прав человека. Труды Института государства и права Российской академии наук, 2, 14-21.

Малер-Матязова, Е. Православное переосмысление «прав человека». URL: http:/ / www.pravoslavie.ru/jurnal/070626004308.htm.

Основы социальной концепции Украинской Православной Церкви. URL: http:/ / www.mospat.ru.

Основы учения Русской Православной Церкви о достоинстве, свободе и правах человека. Приняты на Архиерейском Соборе Русской Православной Церкви 24-29, 06.2008 г. URL: http:/ / www.mospat.ru.

Усманов, Ж. Б. (2015). Понятие «достоинство человека» и его научнофилософская сущность. Молодой ученый, 10, 1530-1532.

Устян, В. Г. (2009). Проблема достоинства человека в святоотеческой традииии и русской религиозной философии: дис. ... канд. филос. наук : 09.00.13. Тула.

Цебенко, С. Б. (2013). Права ююдини у сучасних доктринах православ'я у світлі міжнародних стандартів : дис. ... канд. юрид. наук: 12.00.01. Львів.

\section{References:}

Bandurovskiy, K. (2017). Ponyatiye dostoinstva v filosofii Fomy Akvinskogo [The concept of dignity in the philosophy of Thomas Aquinas]. Dostoinstvo kak istoricheskoye ponyatiye i tsentralnaya kategoriya nashego vremeni: materialy konferentsii (g. Moskva. 2-4 iyunya 2017 g.) [Dignity as a historical concept and the central category of our time: conference proceedings (Moscow, June 2-4, 2017)]. Moscow. 10-11. [in Russian].

Cebenko, S. B. (2013). Prava lyudy 'ny' u suchasny 'x doktry 'nax pravoslav'ya u svitli mizhnarodny'x standartiv : dy's. ... kand. yury`d. nauk : 12.00 .01 [Human rights in the contemporary doctrines of Orthodoxy in the light of international standards: diss. ... Cand. lawyer. Sciences: 12.00.01]. Lviv. [in Ukrainian]. 
Deklaratsiya o pravakh $i$ dostoinstve cheloveka [Declaration of the Rights and Dignity of Human]. URL: http://www.mospat.ru/archive/30728.htm. [in Russian].

Govorun, S. (2006). V opravdaniye chelovecheskogo dostoinstva [In defense of human dignity]. Chelovek. Istoriya. Vest [Human. History. News]. Kyiv: Dukh i Literatura. 34-41. [in Russian].

Gry`shhuk, O. V. (2007). Lyuds `ka gidnist` u pravi: filosofs 'ky j aspekt: dy`s. ... d-ra yury'd. nauk: 12.00.12 [Human dignity in law: philosophical aspect: dis. ... Dr. Jurd. Sciences: 12.00.12]. Lviv. [in Ukrainian].

Kantipenko, E. A. (2015). Razvitiye ponyatiya «Dostoinstvo cheloveka» kak nravstvenno-pravovoy kategorii kontseptsii prav cheloveka [The development of the concept of "Human dignity" as a moral category of the concept of human rights]. Trudy Instituta gosudarstva i prava Rossiyskoy akademii nauk [Proceedings of the Institute of State and Law of the Russian Academy of Sciences], 2, 14-21. [in Russian].

Maler-Matyazova, E. Pravoslavnoye pereosmysleniye "prav cheloveka» [Orthodox rethinking of "human rights"] URL: http:/ / www.pravoslavie. ru/jurnal/070626004308.htm. [in Russian].

Osnovy sotsialnoy kontseptsii Ukrainskoy Pravoslavnoy Tserkvi [Fundamentals of the social concept of the Ukrainian Orthodox Church]. URL: http:/ / www.mospat.ru. [in Russian].

Osnovy ucheniya Russkoy Pravoslavnoy Tserkvi o dostoinstve. svobode i pravakh cheloveka. Prinyaty na Arkhiyereyskom Sobore Russkoy Pravoslavnoy Tserkvi 24-29. 06.2008 g. [Fundamentals of the teachings of the Russian Orthodox Church on dignity, freedom and human rights. Adopted at the Bishops' Council of the Russian Orthodox Church on 24-29, 06/06/2008]. URL: http://www.mospat.ru. [in Russian].

Usmanov, Zh. B. (2015). Ponyatiye «dostoinstvo cheloveka» i ego nauchnofilosofskaya sushchnost [The concept of "human dignity" and its scientific and philosophical essence]. Molodoy uchenyy [Young scientist], 10, 15301532. [in Russian].

Ustyan, V. G. (2009). Problema dostoinstva cheloveka v svyatootecheskoy traditsii i russkoy religioznoy filosofii: dis. ... kand. filos. nauk:09.00.13 [The problem of human dignity in the patristic tradition and Russian religious philosophy: dis. ... cand. Philos. Sciences: 09.00.13]. Tula. [in Russian].

Vlasova, O. V. (2011). Dostoinstvo cheloveka kak nravstvenno-pravovaya tsennost: obshcheteoreticheskoye issledovaniye: dis. ... d.-ra yurid. nauk: 12.00.01 
[Human dignity as a moral value: a general theoretical study: dis. ... Dr. legal Sciences: 12.00.01]. Khanty-Mansiysk. [in Russian].

\section{Анотація}

Бальжик I. А. Гідність і свобода як базові християнські изінооті кониепту прав ююдини. - Стаття.

Інтерпретація питань прав ююдини з державно-правової точки зору та державно-світської ідеології та практики, з одного боку, та з погляду сучасної православної доктрини про людину та їі права, з іншого, не завжди збігаються. Однак обидва підходи грунтуються на тому, що права людини повинні бути непорушними, недоторканними, однаковими для всіх людей, які повинні бути рівними перед законом незалежно від їхньго ставлення до релігіi.

Православна церква стверджує, що приниип свободи повинен відповідати моралі та вірі. Ця гармонізація повинна бути відображена в законі, оскільки, на думку церкви, мораль для всіх одна, так як є суттю Десяти Божих заповідей.

Гідність особистості є основою всього людського існування та взаємодіі з іншими індивідами. Закріплення гідності особистості в правових нормах надає ицій якості існування правових Властивостей, щуо створює можливість розглядати изю категорію як одне з основних і суб'єктивних прав людини.

3 точки зору православ'я, основою гідності людини є віра В те, що кожна ююдина є справді священною, творінням Бога. В основі гідності людини, яка живе в Христі, лежить переконання, щуо Святий Дух присутній у його житті. Відповідно до своєї гідності, ююдина покликана на добрі справи.

Головною особливістю церковного розуміння прав людини є оцінка ролі та місия моральних иінностей у житті сучасного суспільства. Специфріка полягає у наявності порівняльно-оцінного зв'язку християнської антропології та етики з теорією прав людини.

Ключові слова: християнство, православ'я, право, права людини, християнська правова традиція, гідність, свобода. 